\title{
Kerklike eenheid tussen die Nederduitsch Hervormde Kerk van Afrika en die Hervormde Kerk in Suidelike Afrika ${ }^{1}$
}

\author{
I W C van Wyk \\ Hoof: Hervormde Teologiese Opleiding \\ Tydelik-deeltydse dosent: Departement Dogmatiek en Christelike Etiek \\ Universiteit van Pretoria
}

\begin{abstract}
Church unity between the Nederduitsch Hervormde Kerk van Afrika and the Hervormde Kerk in Suidelike Afrika

Church unity between the Nederduitsch Hervormde Kerk van Afrika (NHKA) and the Hervormde Kerk in Suidelike Afrika (HKSA) was a theme that was not even discussed in the past. The reason: the mission policy of the NHKA was that the HKSA should become an independent and separate church as quickly as possible. During the last years many things changed. Article III in the Polity of the NHKA was scrapped. The NHKA is now an open church. The ideology of apartheid, that the NHKA supported in many ways, has crumbled. The time has therefore arrived to start discussing the important theological theme of church unity between these two churches. In this article the view is represented that church unity is not primarily unity in organisation, but unity in faith, confession, teaching and theology. This unity in faith, however, must be made visible. Various forms of ecumenical unity are therefore proposed.
\end{abstract}

\section{INLEIDING}

Die Hervormde Kerk in Suidelike Afrika (HKSA) is 'n produk van die sendingwerk van die Nederduitsch Hervormde Kerk van Afrika (NHKA). Vir dekades lank was die aard

\footnotetext{
1 Hierdie artikel is 'n verwerkte weergawe van 'n lesing gehou op 6 September 1996 tydens 'n simposium oor kerklike eenheid tussen die NHKA en die HKSA wat deur die Raad vir Ekumeniese Sake aangebied is.
} 
van die verhouding tussen die twee kerke deur die volkskerkteologie van die NHKA bepaal. In kort het dit hierop neergekom: die HKSA is op pad na volle en volledige selfstandigheid en onafhanklikheid. Die belydenis oor die eenheid van die kerk was daarom 'n tema wat maar eerder vermy is, of wanneer daar tog daaroor gepraat is, is die gesprek beperk tot die eenheid van die sogenaamde "onsigbare kerk".

Ons staan nou in die tydperk ná "Artikel III". Die nuwe Kerkorde van die NHKA (1997) open in Ordinansie 4.2 die weg vir die skep van andersoortige gemeentes. Volgens Ordinansie 4.3 is lidmaatskap oop vir enige persoon, en volgens Ordinansie 6 is die Hervormde Kerk veronderstel om broederlike betrekkinge met ander Reformatoriese kerke te handhaaf, met hulle saam te werk in ekumeniese liggame en met hulle gesamentlike eredienste te hou. Die nuwe Kerkorde verplig ons dus om die hele verhoudingsbepaling tussen die NHKA en die HKSA weer in oënskou te neem.

Dit is nie net die nuwe Kerkorde wat ons opnuut tot besinning dwing nie, maar ook die nuwe politieke, sosiale en finansiële omstandighede van die land. Op geen manier kan ons met die ou apartheidsdenke voortgaan nie. Ons sal nuut moet dink, sodat ons op 'n verantwoordelike wyse in ons eie tyd, kan voldoen aan die eise wat aan ons gestel word.

Ek wil graag die werkwyse volg deur sover moontlik dogmaties oor die problematiek te besin. Met hierdie werkwyse wil ek my sover moontlik weerhou van 'n worsteling met die kerkhistoriese gesigspunte. Hiervoor is daar enkele redes: (a) daar is té veel onduidelikhede oor die historiese ontwikkelingsgang van die verbintenis tussen die twee kerke. Daar bestaan volgens my mening geen betroubare bron of bronne waarin die ontwikkelingsgang van die verhouding tussen die twee kerke nagelees kan word nie. Ons weet eenvoudig nie presies wat die twee kerke se standpunte in verskillende tydperke oor kerkeenheid was nie. Ons weet nie presies wie almal van 'n ma-dogter verhouding gepraat het nie, en wanneer hulle dit gedoen het nie. Ons weet nie presies of ons van 'n suster-suster verhouding (Mpanza 1995:17-21) ten opsigte van die laaste dekade of wat kan praat nie. Dit is onseker of die NHKA selfs in 'n sekere stadium van suster-suster sou gepraat het. (b) Dit is vrugteloos om oor die verlede te stry. Daar moet eerder 'n nuwe toekoms geskep word. Dit is vrugteloos om mense te probeer oortuig dat daar net een groot geseënde verhouding in die verlede was. Almal weet dit was nie die geval nie. 
Dit is ook vrugteloos om mense te probeer oortuig dat daar ten opsigte van die verlede net in terme van 'n "evil relationship" (Mpanza 1995:4) gepraat kan word. Almal weet dit is nie waar nie. Dit is volgens my oordeel ook kontra-produktief om die politieke ingebedheid van die twee kerke in die verlede (die NHKA as apartheidskerk en die HKSA as ANC-kerk) voortdurend ter sprake te bring. Die verlede sal nooit finaal begrawe kan word nie, maar dit mag nie in 'n mag ontwikkel wat die hede en die toekoms gevange hou nie. My mening is dus dat ons dogmaties helderheid moet kry oor die tema kerkeenheid, sodat ons 'n kerklike visie kan ontwikkel waarmee ons die nuwe millennium kan binnegaan.

\section{DIE IDEAAL VAN KERKEENHEID EN DIE REALITEIT VAN VEELVOUD}

Regdeur die kerkgeskiedenis is daar besef dat die kerk een behoort te wees en een behoort te bly. Hierdie ideaal is egter altyd bedreig en ondergrawe deur die realiteit van die veelvoud van menings en groeperings. Hierdie werklikheid kan waargeneem word in verskillende stadia van die kerkgeskiedenis. In die vroeë kerk was Cyprianus en Augustinus van die min teoloë wat met hierdie problematiek geworstel het. Die vroeë kerk het merkwaardig genoeg min geskrifte opgelewer wat iets oor die tema kerkeenheid te sê gehad het. Die rede: daar was tot en met die Reformasie geen goed ontwikkelde leer oor die kerk nie. Die ekklesiologie het in die groot sistematiese werke vóór die Reformasie feitlik geen aandag geniet nie (Lohse 1988:301). Die konsekwensie hiervan was dat die tema "kerkeenheid" feitlik nêrens indringend behandel is nie. Die eerste werk van werklike belang ten opsigte van hierdie tema, was die verhandeling van Cyprianus, De ecclesiae unitate waarin die biskop van Karthago hom teen enige kerklike afskeiding uitgespreek het. Hy het geoordeel dat daar buite die één ware kerk geen moontlikheid van saligheid is nie. Verder was hy van mening dat biskoppe wat aan afskeidings deelneem en/of dit goedpraat, geen reg het om sakramente te bedien nie. Volgens Cyprianus kan daar dus net een kerk wees en moet daar toegesien word dat daar net een kerk is. Die veelheid móés in die eenheid opgaan. Augustinus het in sy stryd met die Donatiste op die voetspoor van Cyprianus gebly. Sy belangrike bydrae tot die tema "kerkeenheid" is sy uitspraak ecclesia est corpus permixtum. Die kerk is 'n liggaam wat 
uit heiliges (getroue volgelinge) en swakkelinge/verraaiers (hulle wat die Christelike boeke aan die vervolgers gegee het) bestaan. Getroue navolgers van Christus moet volgens hom met die ongehoorsames en verraaiers in die kerk saamleef. Hy het daarom geen ruimte gelaat vir 'n Donatistiese afskeiding nie. Die eenheid van die kerk was vir hom só belangrik, dat hy selfs die heiligheid van die kerk in 'n sekere $\sin$ in gedrang gebring het (kyk na McGrath 1994:407-410).

Die kerk het tot en met die 15e eeu konsekwent aan die oortuigings van Cyprianus en Augustinus vasgehou. In hierdie eeu het die Rooms-Katolieke Kerk egter 'n besluit geneem wat laat blyk dat daar met die veelheid rekening gehou moet word. Hierdie besluit raak die "ketterse beweging" van die Hussiete. Die konsilie van Konstanz het Huss veroordeel en laat doodmaak, maar tog het die konsilie van Basel later in 1433 met die Hussiete die sogenaamde Praagse ooreenkoms aangegaan, waardeur die Hussiete tog 'n klomp voorregte ontvang het. Die implikasie was dat die Rooms-Katolieke Kerk self daardeur erken het dat kerkeenheid nie alleenlik 'n werklikheid is, wanneer almal onder die pous in ' $n$ eenheidstruktuur verenig is nie, maar dat die kerk ook een kan wees wanneer daar ruimte gelaat word vir pluraliteit of veelheid. (Lohse 1988:302-303).

Die Reformasie het die problematiek van veelheid onherroeplik op die agenda van die Christendom geplaas. Die deurvoering van die Reformasie het daartoe gelei dat die eenheid van die Rooms-Katolieke Kerk verbreek is. Die Reformatore self, wou dít egter nie gehad het nie. Hulle wou die Rooms-Katolieke Kerk van binne hervorm, aangesien hulle onwrikbaar aan die eenheid van die kerk geglo het. Trouens; die onderwerp "eenheid tussen die Reformasie en die Rooms-Katolieke Kerk" was nooit eksplisiet behandel nie. Maar, die realiteit is dat kerklike eenheid ná die Reformasie nie weer maklik in terme van organisatoriese strukture gerealiseer sal kan word nie. Die tragiese werklikheid van veelheid en pluraliteit strek natuurlik nog verder. Die nalatenskap van die Reformasie is ook die veelheid van Protestantse konfessies. Op hierdie probleem was die Reformasie ook nie voorbereid nie. Die één teologiese oortuiging waaraan hulle egter vasgehou het, was dié van eenheid sover moontlik.

In die huidige eeu het die Wêreldraad van Kerke (WRK) met dieselfde problematiek te make gekry. Dit is algemeen bekend dat die WRK dit nog altyd ten doel gehad het om eenheid binne die Christendom te bevorder. In verskillende bronne (soos Vischer 
1965) kan die memoranda en besluite van die WRK oor kerklike eenheid nagelees word. By Castro (1992), die vierde sekretaris-generaal van die WRK, kan mens iets te wete kom van die passie wat daar vir eenheid bestaan in die WRK. Die merkwaardige is natuurlik dat die WRK nie vir baie lank met groot ideale van strukturele eenheid geëksperimenteer het nie. Baie spoedig het die besef ontstaan dat daar eerder op die verskeidenheid in die eenheid gekonsentreer moes word. As klassieke voorbeeld van wat op hierdie stadium as die gangbare argument binne die WRK geld, kan na 'n artikel van E C John (1994) verwys word. John berig oor die ekumeniese gesprek in Indië oor kerkeenheid. Hy wys sy kollegas in die WRK daarop dat wat in Indië gebeur, absoluut in lyn is met die laaste besluite van die WRK oor kerkeenheid (John 1994:87-95). Hy meen dat die WRK op die regte spoor is en hy pleit vir begrip dat daar in ' $n$ land soos Indië ruimte gelaat word vir 'n "etnies-konfessionele-identiteit". Hy vra vir insig in die realiteite van groeps-, kulturele-, en etniese identiteit. Hy vra vir aanvaarding van die realiteit dat daar 'n veelheid van kerke in Indië is. Hy glo dat eenheid, veral broederlike eenheid en eenheid in sendingroeping, net dán bevorder sal kan word, wanneer daar ruimte gelaat word vir verskeidenheid.

Die vrae wat nogtans beantwoord moet word, is die volgende: is daar enige Bybelse en teologiese gronde vir verskeidenheid? Indien daar wel is, hoeveel ruimte mag daar vir veelheid en pluraliteit gelaat word? Skep ons nie 'n onaanvaarbare botsing tussen belydenis en werklikheid, wanneer ons onkrities ruimte laat vir verskeidenheid nie?

\section{VEELHEID EN PLURALITEIT IS KENMERKEND VAN DIE CHRISTENDOM}

Ten spyte daarvan dat die Christendom aan die hand van die Nicaeno-Konstantinopolitanum bely dat die kerk één is, was die ervaring van die beginjare van die kerk af, dat hierdie één kerk net in ' $n$ veelheid van kerke, partye en strominge te vinde is. Hiervan lewer Nuwe Testamentici (Lohse 1973; Pelser 1994:321-322; 1995, Strijdom 1995; Van Aarde 1987, 1989, 1995; Theissen 1994) en dogmenhistorici (Kühn 1980:202; Ebeling 1979:371; Schlink 1983:586) getuienis. 
Die getuienis van die Nuwe Testament is die getuienis van die veelheid en pluraliteit van die kerk. Die romantiese beeld van die eenheid van die vroeë kerk, is ' $n$ mite (Van Aarde 1987; 1989:462; 1995). Die Oerchristendom lyk trouens heel Protestants. Dit het uit baie groepe en partye bestaan, en daar was werklik geen oorspronklike eenheid nie (Theissen 1994:71). Hierdie ontdekkings deur die histories-kritiese navorsing het aanleiding gegee tot die beroemde uitspraak van Ernst Käsemann (1970:151) dat die Nuwe-Testamentiese kanon nie die eenheid van die kerk kan begrond nie. Pelser $(1994: 312-313 ; 1995)$ gaan selfs so ver om te beweer dat daar in die Nuwe Testament nie net van één ekklesiologie sprake kan wees nie, maar van verskillende ekklesiologieë. Nuwe-Testamenties kan die eenheid van die kerk daarom slegs 'n eskatologiese saak wees (Ott 1981:431-432).

Die dogmenhistorici se voorstelling van die kerk getuig ook van die verdeeldheid en verskeurdheid van die kerk. Almal weet dat daar weens politieke redes talle kerkskeurings en kerkverdeeldhede was (Schlink 1983:678-681). Almal besef egter nie altyd dat daar ook weens teologiese redes nooit sprake was van werklike kerkeenheid nie. Daar was nooit net één Bybelkanon nie, dieselfde belydenis is nie deur alle Christene en kerke onderskryf nie (hier kan slegs maar na die filioque-kontrovers verwys word), kerke het nie dieselfde ampte (pous en biskop) aanvaar nie, het nie dieselfde kerkregeringstrukture gehad nie en het nie van dieselfde liturgie gebruik gemaak nie. Wanneer Pannenberg (1977:241) uit al hierdie historiese gegewens 'n sistematiese gevolgtrekking moet maak, gaan hy selfs so ver om te beweer dat die bestaan van "konfessies" so vroeg as reeds die 5e eeu waargeneem kan word.

Die kerk was dus nog nooit algeheel één nie. Daar was van die begin af verdeeldheid, partyskappe en selfs konfessionele groeperings. Die vraag is nou of ons in die NHKA en HKSA met ons mense van verskillende kleure, kulture, tale, geskiedenisse, denkpatrone, aspirasies en kerkbegrippe op grond van bogenoemde onproblematies kan argumenteer dat ons in alle opsigte apart behoort te wees en apart behoort te bly? Die antwoord is nee. Onproblematies kan dié twee kerke nie in alles apart bestaan nie. Die rede: ons bely nie die veelheid nie, maar die eenheid van die kerk. Kerke wat aan hulle eie belydenis getrou wil bly, sal eenvoudig na maniere moet soek om groter eenheid onder hulle te bewerkstellig. Dít word gesê, wel wetende dat kerklike eenheid geen 
maklike saak is nie. Hiervan kan die lede van die Tussenkerklike Kommissie wat eenheid tussen die drie Afrikaanse Kerke wil bewerkstellig, getuig (kyk bv na Van der Watt 1987). Ook die NG Kerk kan getuig van die moeilike weg tot kerkeenheid binne die NG Kerkfamilie (kyk bv na Meiring \& Lederle 1979). Die feit bly egter: eenheid móét nagejaag word!

\section{DIE EENHEID, NIE DIE VERSKEURDHEID NIE, WORD BELY}

Die kerk bely met goeie rede die eenheid van die kerk. Daar is talle teksverwysings waarop hierdie belydenis berus. Ons verwys na die volgende: 1 Korintiërs 1:10-30 (waarskuwing teen partyskappe), 1 Korintiërs 12 (eenheid in Gees en baie gawes), Galasiërs 3:27-28 (almal, sonder onderskeid is een in Christus), Romeine 12:3-8 (baie in getal - een in Christus), Handelinge 2:42 (eendragtige volharding in apostoliese diens, gemeenskap, Nagmaal en gebed), Handelinge 4:32 (die gemeenskap van gelowiges is een van hart en siel), Johannes 10:16 (een Herder en een kudde), Johannes 17:20-26 (almal moet een wees soos die Vader en Seun een is), Efesiërs 4:1-6 (een Vader, doop ens). Die vraag is egter wat word met hierdie belydenis bedoel? Wat word hiermee gesê en wat nie?

\subsection{Perspektiewe op grond van die belydenis}

Die kerk wil in die eerste instansie met die epiteton "eenheid" in die Nicaeno-Konstantinopolitanum (381) sê dat die veelheid nie tot kenmerk verhef mag word nie. Dit is die eenheid wat kenmerkend is van die kerk, en nie die veelheid nie. Hierdie belydenis wil sê dat die veelheid nie die eenheid kan ophef nie. Dit kan wel die eenheid versluier, maar dit beslis nie vernietig nie (Schlink 1983:684). Die epiteton "eenheid" word daarom verstaan as 'n byvoeglike bepaling wat 'n vaste kenmerk van die kerk verwoord (Ganoczy 1968:143). Maar, nou weet almal dat wat sigbaar waargeneem kan word, nie die belydenis ondersteun nie. Ons sien nie net eenheid nie, maar ook verskeurdheid. Ten spyte hiervan het die vroeë kerk reg geoordeel om hierdie attribuut nie apologeties uit te lê nie (Küng 1976:266). Ons kan van die apologie afstand doen, aangesien ons hier met 'n geloofsuitspraak en nie met 'n herkenningsteken (nota ecclesiae) te make het nie 
(Pannenberg 1993:442-452). Saam met Ebeling (1979:369-370) kan ons sê dat ons eintlik hier met geloofsattribute te make het. Wat ons bely, is nie meetbaar en waarneembaar nie, maar dit beteken nie dat dit nie 'n werklikheid is nie. Hierdie "belydenisteken", soos wat Moltmann (1975:363-388) dit noem, het daarom net sin in terme van 'n geloofsbelydenis. Ten spyte van die sigbare verdeeldheid, glo ons dus dat die kerk nogtans één is en één behoort te wees.

Die kerk wil in die tweede instansie met hierdie belydenis die uitspraak maak dat die kerk één is, aangesien die kerk van Christus wesenlik net een kan wees. Die kerk (alle ware sigbare kerke) is één aangesien almal in 'n verhouding tot die één Heer, Jesus Christus staan. Net soos Christus één en daarom ondeelbaar is, is sy gemeente ook één en daarom ondeelbaar (1 Kor 12:4-6; Ef 4:4-6). Ten spyte van die veelheid van kerke, is die liggaam van Christus één. Die eenheid van die kerk bly dus 'n realiteit deur al die kerkverdelings heen (Ebeling 1979:373). Dít kan gesê word, omdat die eenheid van die kerk in die eenheid van die handelinge van Christus lê en nie in ons eendragtigheid nie (Schlink 1983:586). Kerkeenheid word dus objektief en nie subjektief gefundeer nie (Van Niftrik 1944:184).

Hierdie geloof dat die kerk wesenlik één is en net één kan wees, word ook deur die werklikheid van die Oerchristendom ondersteun; ten spyte van wat hierbo in verband met die veelheid en verdeeldheid gesê is. Die Oerchristendom was in terme van simbooltaal (mites, rites, normsisteem en gebede) 'n eenheid (Theissen 1994:72-74). Wat hierdie eerste geslagte van gelowiges dus in 'n eenheid saamgebind het, was die gemeenskaplike geloofsinhoude soos die Christologie en die regverdigingsleer wat daarmee saamgehang het (Lohse 1973), die gesamentlike sakramentsvierings asook 'n gemeenskaplike lewenswandel van bekering en liefde. Verder het hulle gemeenskaplike heilige plekke en samekomste gehad wat hulle in 'n eenheid saamgesnoer het. Hulle was gesamentlik oortuig van die openbaring van God in Jesus Christus, en het die gesamentlike doelwit gehad om die outonomie van hulle nuwe religieuse simbooltaal ten alle koste te bewaar en te beskerm (Theissen 1994:74-80). Die Oerchristendom was dus ook nie net 'n bonte verskeidenheid nie, aangesien daar saam geglo, aanbid en gelewe is.

Die derde perspektief wat na my mening op 'n legitieme wyse in die belydenis van die kerk ingelees kan word, is dat eenheid nie die bedoeling het om die verskeiden- 
heid te ondergrawe nie. Eenheid is beslis van die begin af verstaan as eenheid in verskeidenheid. Almal weet dat daar in die beginjare van die Christendom ernstige konflikte en selfs partyskappe was oor die band met die Jodedom en uitbreiding na die heidennasies. Verder was daar in die $2 \mathrm{e}$ eeu groeperinge wat in verskillende verhoudings gestaan het met die Gnostiek (kyk na Theissen 1994:81-85 vir 'n opsomming). Die eenheid van die Oerchristendom het dus verskeidenheid geduld. Eenheid het nie eenvormigheid, maar veelvormigheid beteken. Die Oerchristendom wie se eenheid op solidariteit gegrondves was, het duidelik nie op uniformiteit aangedring nie (Van Aarde 1989:462; 1995; Pelser 1994:322). Daar was egter 'n grens van duldbaarheid wat nie oorgesteek moes word nie. Vir ernstige leerafwykings was daar nie ruimte nie.

Verskeidenheid, veelheid en pluriformiteit is vir Karl Barth egter nie sulke duldbare sake nie. Hy beklemtoon die eenheid so sterk, dat hy geen oog vir die verskeidenheid het nie. Volgens hom kan daar van kerk in die meervoud slegs dán op 'n legitieme wyse sprake wees, wanneer dit om lokaal verwyderde gemeentes/kerke handel. Elke gemeente is volgens hom volledig communio sanctorum. Hierdie lokaal verwyderde gemeentes sal noodwendig van mekaar in gestalte verskil, aangesien hulle die taal, kultuur en denkwyse van dié bepaalde omgewings sal aanneem. Dit beteken egter nie 'n veelheid van kerke nie, aangesien elke gemeente deel is van die één kerk van Christus. Verwyderdheid hef dus nog nie eenheid op nie (Barth 1960:749-750). Die

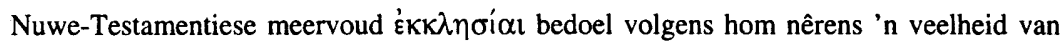
kerke wat in terme van hulle wese nie met mekaar identies is nie. Daar word bedoel: kerke wat reëel dieselfde is, maar wat net lokaal van mekaar verwyderd is. Die verskil in taal, kultuur en denkwyse mag nie van die gemeentes/kerke verskillende kerke maak nie - en indien dit gebeur, is dit 'n fout, aangesien hierdie dinge nie konstitutief vir kerkwees kan wees nie (Barth 1960:750-753). Naas hierdie verwyderde veelheid van gemeentes, is daar vir Barth geen ander legitieme veelheid van kerke nie. Enige ander kriterium vir veelheid sal volgens Barth die eenheid ophef. Barth (1960:754) sê daarom:

Es gibt aber keine theologische, keine geistliche es gibt auch keine biblische Rechtfertigung der Existenz einer Vielheit solcher real getrennter, sich innerlich und darum auch äußerlich gegenseitig ausschließender Kirchen. 
Viele Kirchen in diesem Sinn bedeutet: viele Herren, viele Geister, viele Götter. Keine Frage: in dem Maß, als die Christenheit in wirklich verschiedenen und entgegengesetzten Kirchen existiert, in dem Maß leugnet sie praktisch, was sie theoretisch bekennt: die Einheit und Einzigkeit Gottes, Jesu Christi, des Heiligen Geistes. Alle guten Gründe für die Entstehung solcher Kirchenspaltung und alle schweren Hindernisse, sie zu beseitigen, alle Interpretationen und Milderungen, die ihr widerfahren mögen, ändern nichts daran, $\mathrm{da} \mathfrak{B}$ jede Kirchenspaltung als solche ein finsteres Rätsel, ein Skandal ist.

Soos reeds gesê, het Barth 'n baie eensydige standpunt aangesien hy geen ruimte laat vir veelvoud en verskeidenheid nie. Feitlik almal sal met Barth oor die gedagte van eenheid saamstem, maar dan moet daar van eenheid van die veelheid sprake wees. Soos wat ons reeds gesien het, is veelheid en pluraliteit werklikhede wat nie weggewens kan word nie. Ek wil my by die dogmatikus Gerhard Ebeling (1979:374) aansluit en 'n pleidooi lewer dat daar meer toleransie teenoor pluraliteit in die kerk sal wees. Hierdie pleidooi word met die bedoeling gelewer dat die eenheidsideaal nie ondergrawe mag word nie. Nooit mag die (legitieme) veelheid die eenheid verhinder nie, en veral mag die veelheid nie uitsluitend van aard wees nie (Ebeling 1979:372). Verskeidenheid is legitiem, maar nie verdeeldheid nie. Daar kan byvoorbeeld selfs met reg teen "modaliteite" in die kerk beswaar gemaak word (Van Genderen 1993:646). Ten spyte van hierdie aanhoudende klem op die eenheid, kan daar nogtans gestel word dat uniformiteit nie nodig is vir eenheid nie. Daar kan en mag ' $n$ gesonde verskeidenheid in die kerk wees, maar dít mag nie lei tot 'n sondige verskeurdheid nie. Of die verskeidenheid "gesond" is, sal daarvan afhang of daar ruimte is vir gesamentlike eredienste en Nagmaal (Van Wyk 1996:28-30).

Die ruimte vir veelheid kan teenoor die aanspraak op eenheid gehandhaaf word, aangesien die belydenis oor die katolisiteit van die kerk dit moontlik maak. Katolisiteit beteken: die kerk is één ten spyte van die ruimtelike en historiese gebrokenheid en onenigheid. Ignatius, die eerste gebruiker van die woord, het gesê dat die kerk katoliek is, omdat Christus in al sy gemeentes reg oor die wêreld teenwoordig is. Elke afsonderlike gemeente is daarom vir hom versinnebeelding van die een universele kèrk. Karl Barth (1960:783) het egter 'n stappie verder gegaan. Hy weier om voorbehoudloos oor 
gemeentes as versinnebeelding van die algemene kerk te praat. Volgens hom is daar slegs van katolisiteit sprake, waar daar sprake is van ware kerke. Katolisiteit is volgens hom: ten spyte van historiese en ruimtelike diskontinuïteit, is daar identitele kontinuïteit waar daar sprake is van 'n ware kerk. Katolisiteit beteken dus vir Barth: ware kerke hier en daar, nou en toe is één omdat daar kontinuïteit is in dít wat die waarheid van 'n kerk konstitueer. 'n Kerk is dus katoliek, of hy is nie kerk nie. Barth (1960:784) sê daarom:

\begin{abstract}
Credo catholicam ecclesiam heißt schlicht: ich glaube ... die Existenz einer Gemeinde, die in ihrem sie zur christlichen Gemeinde machenden Wesen in allem Wechsel ihrer Gestalt unveränderlich ist, die sich also in ihrem Wesen nie verändert hat und auch nie vèrändern darf und wird. Und negativ: ich glaube, nicht, daß eine Gemeinde anderen Wesens christliche Gemeinde sei. Zusammengefaßt: ich glaube die Existenz einer wahren, nicht die einer falschen Kirche.
\end{abstract}

'n Mens sal seker nie van Barth op hierdie punt kan verskil nie. Die vraag is egter: kan daar verskillende kulturele gestaltes van die ware kerk wees - of kan die ware kerk verskillende kulturele gestaltes aanneem? Vir Barth is die kerk slegs dán katoliek wanneer die kerk in wese dieselfde bly wanneer die kerk gestalte aanneem onder verskillende tale, kulture en rasse. Die kerk is en bly die katolieke kerk slegs daar, waar die aardse realiteite nie belangriker raak as die geloofsrealiteite nie. Barth (1960:785786) weier dus om van 'n Duitse en Afrika-Christendom te praat. Hy sê daar is slegs so iets soos die Christendom in Duitsland en Afrika. Daar kan volgens hom nie so iets soos die Church of England wees nie, slegs die kerk in Engeland. Hy kritiseer die kerk in Suid-Afrika dat die kerk die maatskaplike en politieke verskynsels gebruik as riglyne en voorbeelde vir die gestaltegewing van die kerk. Die kerk is vir Barth dus iets uniek. Die natuurlike werklikhede van die lewe mag hierdie uniekheid nie ondergrawe nie. Indien dit wel gebeur, word die katolisiteit van die kerk ondergrawe - die oortuiging dat die kerk oral en altyd dieselfde/identiek behoort te wees.

Waarmee ' $n$ mens met Barth moet saamstem, is dat taal en kultuur nie die identiteit van die kerk mag bepaal nie. Waarmee 'n mens egter nie kan saamstem nie, is dat taal en kultuur eintlik glad nie ekklesiologies verreken mag word nie. Taal en kultuur 
is eenvoudig ekklesiologies ter sake. Sekerlik kan dit net onder sekere voorwaardes (soos dat dít nie die eintlike identiteit van 'n kerk sal bepaal nie) ter sprake gebring word, maar algeheel kan ons dit nie wegwens nie. Oor katolisiteit, in terme van die vraagstelling wat hier behandel word, wil ek dus soos volg redeneer: gemeentes en kerke wat op grond van taal en kultuur as eiesoortig getipeer kan word, versteur nie die eenheid van die kerk as hulle die kontinuïteit van die ware geloofstradisie verseker. Wanneer gemeentes en kerke met ander woorde die oud-kerklike en Reformatoriese belydenistradisie oorneem en bewaar, kan hulle 'n eie kerklik-kulturele identiteit ontwikkel, omdat die katolisiteit van die kerk dit toelaat. Die eenheid en die katolisiteit van die kerk is dus keerkante van dieselfde saak. Binne die eenheidsgedagte is daar ruimte vir verskeidenheid, terwyl die katolisiteitsgedagte weer verskeurdheid verhinder. Die NHKA en die HKSA kan dus na my mening kerke bly met elk hulle eie kulturele identiteit, mits hierdie vergunning van eie identiteit nie die belydenis van die kerk oor die eenheid ondergrawe nie. Dié twee kerke kan kultureel eie-aardig wees, mits hulle nie die kontinuïteit met die ware geloofstradisie prysgee nie. Vir hierdie standpunt kan ek my beroep op die volgende teoloë: Calvyn (Ganoczy 1968:153; Smidt 1972:13-14; Nijenhuis 1994:35-47); Weber (1972: 609); Pannenberg (1972:153-154; 1977:234-240); Küng (1976:274-275); Lohse (1978: 246-247); Tetz (1984); Heyns (1988:379); Elert (1988:436); McGrath (1994:423-425).

\subsection{Konklusies uit die belydenis}

Met alles in ag genome wat reeds gesê is, is dit duidelik dat die twee kerke, die NHKA en die HKSA, met mekaar één is omdat beide met die liggaam van Christus één is. Eenheid tussen die twee kerke is daarom reeds 'n werklikheid. Dit is nie iets wat nog eers gerealiseer moet word nie, omdat beide die betrokke kerke deel is van die sogenaamde 
"onsigbare kerk." Volgens Calvyn is die "onsigbare kerk" die gemeenskap van die uitverkorenes. Dit sluit al die gelowiges van alle tye en alle kerke in. Hierdie gemeenskap kan net onsigbaar wees, aangesien net God die individue van hierdie gemeenskap ken (Nijenhuis 1994:36). Hierdie gemeenskap is 'n eenheid, aangesien daar net één God is met één uitverkiesing. Die implikasie is, dat die kerke van die Reformasie en die Rooms-Katolieke Kerk één is, ten spyte van die verdeeldheid (Ganoczy 1968:142-148). Dieselfde argument geld dus ten opsigte van die NHKA en die HKSA. Eenheid is daarom nie iets wat nog gesoek en waargemaak moet word nie. Die kerke is reeds één. Hulle kan ook nie anders as om één te wees nie, aangesien die eenheid in God lê. Aangesien daar net één God is wat aanbid word, ís die aanbidders één. Teen wil en dank, ís die gelowiges één huisgesin. Hulle ís mekaar se broers en susters (Van Selms 1952:142). Die ware geestelike kerk is na sy wese dus 'n eenheid. Die eenheid met sy Heer en die eenheid onderling is van die begin van die kerk af daar. In geloof en in liefde ken hierdie kerk geen verskeurdheid nie. Die eenheid van die onsigbare of geestelike kerk is en bly ' $n$ gegewendheid. Dit hoef nie eers gerealiseer te word nie.

Wanneer ons sê dat die onsigbare kerk één is, en dat die twee ter sprake kerke (of dan minstens die uitverkore lidmate van die twee kerke) één is, mag daar nou in die tweede instansie nie tot die gevolgtrekking gekom word dat die twee sigbare gestaltes van die twee kerke nie één hoef te wees nie (of nog erger: nie één mag wees nie). Só 'n argument is illegitiem en kom neer op niks minder as 'n stuk Platonisme nie (Barth

2 Ek hou by die uitdrukking "onsigbare kerk" ten spyte van besware deur Nuwe-Testamentici (soos bv Pelser 1994:325) wat beweer dat daar vir hierdie gedagte geen basis in die Nuwe Testament te vinde is nie. Ek hou by hierdie uitdrukking ten spyte daarvan dat sistematiese teoloë self (Van Niftrik 1944:182-184; Brunner 1964:152) beweer dat hier op 'n onregmatige wyse oor kerk gepraat word, omdat hierdie term 'n saak ter sprake bring wat wel deeglik ' $n$ Bybelse saak is. Binne die hele Reformatoriese tradisie is dit tot vandag nog gebruiklik om van die sigbare en onsigbare kerk te praat (Ott 1981:422-427). Selfs die RoomsKatoliek, Hans Küng (1976:264), praat op hierdie wyse oor kerk. Die terme "sigbaar-onsigbaar" moet in die eerste instansie as eskatologiese begrippe verstaan word teen die agtergrond van die komende oordeel oor ware en valse gelowiges. Verskillende ander begrippe soos byvoorbeeld corpus permixtum word vir dieselfde saak gebruik. Die begronding is veral in die gelykenisse te vinde (Schlink 1983:687). In die tweede instansie wil ek daarop wys dat die term "onsigbaar" geldigheid het omdat hier van kerk gepraat word as 'n grootheid groter as ons eie werklikheid (Pannenberg 1977:202). Die onsigbare kerk is die versameling van al die ware gelowiges deur al die eeue. Luther (WA 54,184,31-36) het geoordeel dat nie alleenlik mense soos Bernhard van Clairvaux en Fransiskus van Asissi lede van hierdie kerk is nie, maar selfs ook Johann Tetzel, wat na sy mening tog ook 'n ware gelowige was. Die ware onsigbare kerk bestaan dus volgens Luther uit al die ware gelowiges van alle tydperke en alle kerke (insluitend die RoomsKatolieke Kerk WA 26,147,13-20). 
1986:219). Daar kan ook nie geargumenteer word dat die onsigbare eenheid in der mate adekwaat is, dat daar nie eers met ander kerke wat die kenmerke van 'n ware kerk openbaar, gepraat mag word oor eenheid nie. Só 'n standpunt het B J Engelbrecht ingeneem. Engelbrecht (1978:294) meen dat daar slegs oor sigbare eenheid met kerke gepraat word, as ons vermoed dat hulle nie deel van die onsigbare kerk is nie; met ander woorde, wanneer die kenmerke van 'n ware kerk nie by hulle teenwoordig is nie. Die konsekwensie van sy standpunt is dat mens net met valse kerke oor die ware leer praat en nie met ware kerke oor die gestaltegewing van die reeds bestaande eenheid nie. Hierdie tipe van argumentvoering is net eenvoudig nie in lyn met die Calvinistiese tradisie nie. Karl Barth het eenkeer selfs die volgende radikale uitspraak in sake kerkeenheid gemaak. Barth (1960:747-748) het gesê dat, aangesien die kerk een is, die sigbare en onsigbare kerk, die ecclesia militans en die ecclesia triumphans, asook die volk Israel in die ganse geskiedenis ante et post Christum natum en die Christelike kerk één is en één móét wees. Heinrich Ott, Karl Barth se opvolger in Basel, is ook van oortuiging dat ons nie langer op grond van die argument van die "onsigbare kerk" die verskeurdheid kan legitimeer nie. Hy wys ons daarop dat die Reformatoriese vraagstelling oorspronklik om die individuele heilsvraag gehandel het, en nie om die vraag na die eenheid van die kerk nie. Hy pleit nou daarvoor, dat hierdie ou Reformatoriese teologumenon nie verder misbruik sal word vir 'n saak wat nie Bybels verdedig kan word nie. Hy pleit (as Calvinis) daarvoor dat ons nie langer op die verskille tussen kerke moet konsentreer nie, maar op die gemeenskaplike. Slegs wanneer dít gebeur, sal ons in staat gestel word om aan ons eintlike opdrag uitvoering te gee, naatmlik diens in die wêreld (Ott 1981:422-427). Ten spyte daarvan dat ons ruimte wil laat vir kulturele verskeidenheid, sê ons ook dat verskeurdheid en apartheid ten alle koste nie God se wil is vir die normale ontvouing van die kerk nie. Verskeurdheid en apartisme is skuld en sonde en daar moet om vergewing gebid word en omkeer moet plaasvind (Van Niftrik 1944:185; Barth 1986:219-220; Balke 1990:264268). Die kerk was nog nooit sonder verskeurdhede nie, maar kan ook nooit sonder die wil bestaan om die kerke te verenig nie, aangesien die algehele opheffing van gemeenskap tussen kerke onchristelik is (Schleiermacher 1984:301-303). Kerkeenheid is dus ook 'n opdrag aan die sigbare kerk. 


\section{EENHEID IS OOK 'N OPDRAG AAN DIE SIGBARE KERK}

Die argument oor die eenheid van die kerk kan duidelik nie tot die sogenaamde "onsigbare kerk" beperk word nie. Die vraagstelling én die antwoord op die vraagstelling, het ook met die sogenaamde "sigbare kerk" te make. Almal weet dat die sigbare, waarneembare kerk onontbeerlik is. Luther het selfs van die heilsnoodwendigheid van lidmaatskap van die sigbare kerk gepraat. Op voetspoor van Cyprianus het hy gesê dat daar geen moontlikheid van heil buite die sigbare kerk is nie. Daarom kon hy in 1522 in 'n "Kirchenpostille" sê:

wer Christum finden soll, der muß die kirchen am ersten finden ... Nu ist die kirch nit holz und steyn, Bondern der hauff Christglewbiger leutt, tzu der muß man sich haliten und sehen, wie die glewben, leben und leren; die haben Christum gewißlich bey sich, denn außer der Christlichen kirchen ist keyn warheytt, keyn Christus, keyn selickeyt

(Luther, WA 10/1, 1, 140, 8-17)

Calvyn huldig dieselfde mening as Luther oor die sigbare kerk. In sy Institusie van 1539 beskryf hy die kerk as die "moeder van die geloof" of as die "sigbaar dienende moeder". In die uitgawe van 1543 neem hy die argument verder en sê dat dit 'n noodwendigheid is dat dié kerk waaraan ons behoort, 'n eenheid moet wees. Aangesien die onsigbare kerk één is, móét die sigbare kerk volgens hom ook één wees. Daar moét volgens hom onderlinge eenheid wees as die kerk haar roeping wil volvoer (Ganoczy 1968:149-165; Jonker 1987). Bitter min teoloë sal vandag van hierdie standpunt van Calvyn wil verskil. Feitlik almal besef dat mens onder geen omstandighede die ware geestelike kerk van die werklike sigbare kerk mag skei nie. Hierdie twee dimensies van kerkwees hang mos onlosmaaklik met mekaar saam (Lohse 1988:311).

Die argument: omdat die geestelike kerk één is, die sigbare kerk ook één is en één moet wees, kan op verskillende maniere begrond word. Dit kan in die eerste instansie met eksegetiese argumente begrond word. Hier kan onder andere na Johannes 17 en die Eerste Brief aan die Korintiërs verwys word. Hierdie Bybelgedeeltes, soos baie ander, laat dit net eenvoudig nie toe dat partyskappe, veelheid en verskeurdheid as normaal en 
goed voorgehou kan word nie. Jesus en Paulus se oproepe tot eenheid geld die werklike aardse kerk, en wie hierdie oproepe wil ondergrawe, ondermyn hulle woorde en werk (Balke 1990:264). Ter begronding van hierdie tese, kan daar ook van 'n argument uit die teologiegeskiedenis gebruik gemaak word.

Nadat die $N G B$ in artikel 27 die oortuiging uitgespreek het dat daar net één kerk kan wees wat uit al die ware gelowiges bestaan, word daar in artikel 28 gevra dat al die gelowiges hulle by die ware kerk moet aansluit "sodat die eenheid van die kerk bewaar kan word". Die Heidelbergse Kategismus argumenteer in antwoord 54 ook dat kerke (die vergaderings van die uitverkorenes) eenheid onder mekaar moet weerspieël. Die derde begrondingsargument wat gebruik kan word, is dié van verwysing na eietydse Calviniste. Karl Barth (1960:756-762) is beslis daarin dat hierdie belydenis nie net die "onsigbare kerk" raak nie. Hy sien eenheid daarom ook nie net as 'n gegewendheid nie, maar ook as 'n indikatief. Eenheid moet volgens hom ook gestalte kry. Dit is vir hom 'n etiese opgawe, opdrag en bevel. Eenheid is vir hom nie net 'n verborge saak van die geloof nie, maar ook 'n saak wat konkreet gestalte moet kry. Jürgen Moltmann (1975:364-366) het Barth se argument verder ontwikkel. Volgens hom moet die attribute, of die belydenistekens van die kerk, nie net as geloofstellings (Glaubenssätze) verstaan word nie, maar ook as hoopstellings (Hoffnungssätze) en handelingstellings (Handlungssätze). Die attribute is volgens hom dus nie net geloofsuitsprake nie, maar ook eskatologiese en etiese uitsprake. Geloof, hoop (eskatologie) en liefde (etiek) hoort vir hom in die ekklesiologie saam. Dit wat ons glo, daarop hoop ons. Dit wat ons glo, dit moet in ons lewens gestalte kry. Om hierdie rede is die eenheid van die kerk wat ons glo, ook 'n etiese opgawe, ten spyte daarvan dat volkome eenheid eers in die koninkryk van God 'n werklikheid sal wees. Hierdie argument word nie net deur die Duitsers gevoer nie. Ook Hollanders (Balke 1990:261) dink oor hierdie saak dieselfde. Dit is ook nie net Calviniste wat hierdie mening deel nie, ook Lutherane (Pannenberg 1972:155) is van oortuiging dat die attribute nie net eienskappe is wat aandui hoe en wat die kerk is nie, maar dat dit kriteria is waarna gestreef moet word. Daar is onder die huidige geslag van vooraanstaande teoloë eenstemmigheid dat eenheid ook 'n etiese opgawe is. Aangesien die kerk één is, moet daar na eenheid gesoek word. Ten spyte daarvan dat eenheid nie bewerk kan word nie, moet almal, aangesien hulle in Christus één is, na eenheid soek (Ebeling 1979:374; 
Schlink 1983:586; Van Aarde 1989:463). Die groot vraag is egter nou: watter gestaltes kan en moet kerklike eenheid aanneem? Op watter wyse moet die NHKA en die HKSA één wees, sodat hulle getuienis kan aflê van die eenheid wat reeds tussen hulle bestaan?

\subsection{Gestaltes van kerklike eenheid}

\subsubsection{Kerklike eenheid kry sigbare gestalte deur één te wees in die geloof}

Ons het hierbo gesê dat die eenheid van die kerk 'n reeds bestaande werklikheid is. Eenheid kan dus nie geskep of georganiseer word nie. Dit kan en moet egter gestalte aanneem. Ware eenheid hoef daarom duidelik nie in organisasie lê nie, maar dit kan en moet wel in geloof lê. Eenheid kry gestalte wanneer gelowiges dit in die geloof eens is. Hulle sal dit eens wees in die geloof, wanneer hulle dit eens is oor die waarheid van God in Christus. Deur eendragtig in die waarheid te glo dat God in Christus ons Redder is, gee aan die kerk 'n gestalte van eenheid (Van Niftrik 1944:185; Van Aarde 1989:461469).

\subsection{Kerklike eenheid kry sigbare gestalte deur één te wees in belydenis}

Die gemeenskaplike geloof in die drie-enige God word in die belydenis van die kerk tot uitdrukking gebring. ' $n$ Volgende gestalte van sigbare kerkeenheid is daarom die eenheid in belydenis (Heyns 1988:378). Trouens, sigbare eenheid is net moontlik op grond van eenheid in belydenis. Hierdie gestalte van eenheid kom in die eerste instansie tot stand deur 'n gemeenskaplike aanvaarding van die belydenisse van die vroeë kerk. Om gesamentlik op die vroeë kerk en sy belydenisse gerig te wees, verseker nie net eenheid tussen kerke vandag nie, maar ook met die kerk deur al die eeue (Pannenberg 1977:211-218). Sigbare eenheid kan in die tweede instansie tot stand kom wanneer kerke, naas die gemeenskaplike aanvaarding van die vroegkerklike simbole, mekaar se belydenisskrifte en belydenisuitsprake erken en aanvaar (Schlink 1983:701-703). Kerke behoort in hierdie sensitiewe saak werklik met mekaar die ekstra myl te loop. Niemand minder nie as Calvyn, het in hierdie opsig die voorbeeld gestel. Hy was by uitstek 'n groot ekumeniese figuur (Nijenhuis 1959). Hy het uit sy pad gegaan om eenheid onder die Protestante te bewaar en te bevorder, sonder om die waarheid van die evangelie te relativeer (Smidt 
1972:12). Sy ekumeniese gesindheid het meegebring dat hy groot toleransie in belydenisaangeleenthede geopenbaar het (Balke 1990:266). Hy was bereid om kompromieë aan te gaan en dit het meegebring dat hy 'n belangrike rol gespeel het rondom die totstandkoming van die Consensus Tigurinus (1549) en die Harmonia Confessionum (1581). Calvyn was daarvan oortuig dat daar ten alle koste eenheid binne die Reformasie moes wees. Hierdie eenheid moes egter volgens hom op grond van teologiese motiewe, en nie op grond van politieke motiewe nie (soos in die geval van die Wittenberg Konkordie) tot stand kom. In 'n ware ekumeniese gees en gesindheid het hy daarom gepoog om Zwingli en Luther, Switsers en Duitsers tot konsensus te bring in sake die Nagmaal. Hierdie pogings het vrugte afgewerk in die ondertekening van die Consensus Tigurinus in Mei 1549 (vgl Nijenhuis 1959:112-131 vir die ontstaansgeskiedenis). Calvyn het as ekumeniese figuur nie net gepoog om ander met mekaar te versoen nie, maar hyself was bereid om konsensus met ander te soek. Hy het uit sy pad gegaan om konsensus met die Duitse Lutherane te bereik. Hy het eindelose pogings aangewend om die eenheid met die Duitsers uit te bou. Hy het in groot geduld talle briewe aan Melanchthon geskryf in die hoop dat hulle tot konsensus sal kom oor belydenissake. Hierdie geduld en toleransie het uiteindelik gekulmineer in die aanvaarding van die Harmonia Confessionum (1581) waarmee die Calviniste groot gedeeltes van die Lutherse belydenisskrifte aanvaar het (Nijenhuis 1994:44-47) ${ }^{3}$.

Die NHKA en die HKSA sal aan hulle gegewe eenheid sigbare gestalte gee, wanneer hulle na eenheid in belydenis streef. Daar moet nie slegs eenstemmigheid tot stand kom oor die verstaan en betekenis van die oudkerklike simbole nie, maar daar moet ook eenstemmigheid kom oor die belydenis vandag. Die implikasie is dat die moeilike weg bewandel sal moet word om tot konsensus te kom oor byvoorbeeld die voorsienigheidsleer, aangesien hierdie belydenis deur die voorvadergeloof bedreig word. Hierdie moeilike weg moet bewandel word, en ons moet ons nie op die maklike sypaadjie begewe van die ekumeniese bewegings nie, waar eenheid geskep wil word deur 'n gemeenskaplike vyand te beveg nie (Elert 1988:437; Slenczka 1973).

3 Die volharding van Lutherane en Calviniste op hierdie weg van soeke na leereenheid het op 16 Maart 1973 vrugte opgelewer met die aanvaarding van die Leuenberg Konkordie. 


\section{Kerklike eenheid tussen die NHKA en die HKSA}

... daB ich mit allen Verehrern Christi euren Stuhl für vom Satan besessen und für den verdammten Thron des Antichristen halte ... und ihm als dem Hauptund Todfeind Christi nicht mehr gehorchen und verbunden sein will ... Wenn ihr in dieser Raserei verharrt, so verdammen wir euch und übergeben euch samt dieser Bulle und allen Dekretalen dem Satan zum Untergang des Fleisches, auf daß euer Geist mit uns errettet werde am Tage des Herrn.

(Luther, WA 6,604,19-38 Adversus execrabilem Antichristi bullam 1520)

Ander kerke is nou weer nie noodwendig valse kerke nie, maar openbaar tog verskillende grade van leerverskille en selfs leerafwykings met die eie kerk. Die vraag is dus: hoe raak verskillende grade van leerverskille die kerklike eenheid? Volgens Luther hang die graad of intensiteit van kerkeenheid met sulke kerke af van die graad van leerverskil en leerafwyking. Kerklike eenheid was vir Luther ook nie moontlik met bevrydingsteoloë (en hulle gemeentes) soos Thomas Müntzer nie. Müntzer het geleer dat die kruis van Christus eers deur die kruise van die lydendes heilsbetekenis kry. Luther het geoordeel dat Müntzer op hierdie wyse 'n nuwe tipe van werkgeregtigheid geskep het en daarom die leer van die regverdiging ondergrawe. Met iemand wat die hart van die evangelie ondergrawe, kon Luther nie eenheidsbande bewaar nie. Luther kon ook nie met Zwingli as gevolg van leerverskille oor die Nagmaal, tot volle Nagmaals- en kerklike gemeenskap kom nie. Hy het hom egter nie verketter (soos die pous) of veroordeel (soos Müntzer) nie. Hy het, net soos Calvyn, uit sy pad gegaan om die leerverskille uit die weg te ruim. Toe hy nie daarin kon slaag nie, het hy maar besluit om distansie teenoor hom te handhaaf en om hom in liefde te verdra tot sover sy gewete dit mag toelaat (Lohse 1988:313). Kerklike eenheid het dus vir Luther verskillende grade van eenheid geïmpliseer, afhangende van die graad van ooreenstemming in leer. Indien leereenheid nie bereik kon word nie, was sigbare eenheid nie moontlik nie. Maar, indien leereenheid moontlik was, móés sigbare eenheid gestalte kry in één kerklike struktuur.

Met die verloop van die tyd het Luther ' $n$ al meer en meer gematigde en versoenende houding ingeneem teenoor mense en kerke met ander leermenings. Die eenheid van leer het vir die latere Luther nie volkome konsensus in alle besonderhede beteken nie. Hy het byvoorbeeld die afwykende thenings van Melanchthon in sake die leer oor die 


\subsubsection{Kerklike eenheid kry sigbare gestalte deur één te wees in leer}

Die belydenis van die kerk word in leerstellings verwoord. Sigbare eenheid moet daarom eenheid in leer wees. Hieroor was Calvyn (Inst IV, 1, 9; Botha 1979) baie beslis. Die implikasie is daarom dat kerke met teenoorstaande leermenings, nie één kan wees nie. Wanneer daar dus nie eenheid in leer is nie, kan daar nie sprake van sigbare eenheid wees nie. Eenheid is dus nie met alle kerke en godsdienstige groeperings moontlik nie. Ware en valse kerke kan nie een wees nie (Balke 1990:265; Van Genderen 1993:646; Lohse 1995:299-301). Volgens Luther was dit dus 'n onmoontlikheid dat die "Lutherse Kerk" met die Rooms-Katolieke Kerk 'n eenheidsgestalte kon vorm. Op grond van die feit dat sy "kerk" volgens hom 'n ware kerk is, en die Rooms-Katolieke Kerk 'n valse kerk, omdat dit nie die kenmerke van 'n ware kerk ${ }^{4}$ openbaar nie, kon hy die volgende oor beide groeperinge sê: "Hie mit haben wir nu beweist, das wir die rechte alte Kirche sind, mit der gantzen heiligen Christlichen Kirchen ein Cörper und eine gemeine der Heiligen", terwyl hy aan die Rooms-Katolieke sê: "Beweist nu auch jr Papisten, das jr die rechte alte Kirche oder jr gleich seid. Aber das kündt jr nicht thun, Sondern ich wil beweisen, das jr die Newe, falsche Kirche seid, die jmer von der Alten rechten Kirchen abtrünnig, des Teufels Hure und Schule wird" (Luther, WA 51, 487, 18-23)

Dit was dus in sy eie denke ' $n$ onmoontlikheid om aan 'n eenheidstruktuur vir Lutherane en Katolieke te dink. Die enigste oplossing was dat die Katolieke die RoomsKatolieke Kerk moes verlaat en by die Reformasie moes aansluit. Indien hulle dít nie wou doen nie moes hulle weet, soos wat Luther hulle gewaarsku het:

\footnotetext{
${ }^{4}$ Luther was van oortuiging dat die een, ware kerk nie met uiterlike middele herkenbaar is nie. Dit is slegs die geloofsoog wat hierdie één kerk sal kan raaksien. Die geloof sal egter in sy oordeel nie fouteer om 'n kerk as ' $n$ ware kerk, en daarom as deel van die een liggaam van Christus te identifiseer nie, wanneer daar 'n sekere aantal kentekens in só 'n kerk teenwoordig is nie. Die aantal kenmerke van die ware kerk (notae ecclesiae) het by Luther deur die loop van die jare in getal gegroei. In 1527/30 het hy in sy Jesajavoorlesing gesê: "Das einzige, ewige und unfehlbare Kennzeichen der Kirche ist zu allen Zeiten das Wort gewesen" (WA 25,97,32). Teen 1539 (Von den Konziliis und Kirchen) praat hy van sewe kentekens, naamlik: die Woord, die doop, die Nagmaal, die sleutels van die koninkryk, die beroep en ordening van predikante en biskoppe, die gebed, die dra van die kruis en die ly van aanvegtinge. In 1541 (Wider Hans Worst) praat hy dan uiteindelik van tien kentekens, naamlik: die doop, die Nagmaal, die sleutels, die amp van prediker, die Apostolicum, die Onse Vader, die eerbied aan die owerhede, die lofprysing aan die huwelik, lyding, die afsweer van wraak teen die vervolgers.
} 
Nagmaal mettertyd leer duld. By die opstel van die Wittenberger Konkordie (1536) was Luther ook bereid om kompromieë aan te gaan. Aanvanklik het hy byvoorbeeld daarop gestaan dat daar iets gesê word oor die manducatio impiorum (die spysiging van die goddelose). Later het hy ingestem dat daar slegs van die manducatio indignorum (die spysiging van die onwaardiges) gepraat word. Op grond hiervan blyk dit dat Luther die eenheid in leer as voorwaarde vir kerklike eenheid gesien het, maar dat die eenheid in leer vir hom nie beteken het dat bepaalde dogmatiese formulerings in 'n leerwetlike sin aanvaar moes word nie. Wat vir Luther van belang was, was dat die basiese uitleg van bepaalde geloofsartikels dieselfde moes wees (Lohse 1988:314).

Calvyn was dit met Luther se oortuigings volledig één. Ook hy was daarvan oortuig dat absolute volledige eenstemmigheid in leeraangeleenthede nie 'n voorwaarde vir kerklike eenheid kan en mag wees nie. Hy het in die lig van hierdie argument die gedagte van die Capita doctrinae ontwikkel. Hy het geoordeel dat daar 'n hiërargie van leeruitsprake bestaan. Sommige leerstellings soos dié oor die twee nature van Christus en die drie-eenheid van God is byvoorbeeld belangriker as die uitsprake oor die gestalte van die "liggaam" in die hiernamaals en die herkoms van die doop. Daar behoort volgens Calvyn, wanneer kerke eenheid tot uitdrukking wil bring, eenstemmigheid te wees ten opsigte van die groot en belangrike leeraangeleenthede. Oor die kleiner en minder belangrike sake kan daar maar verskille wees. Dít moet kerklike eenheid nie verhoed en dwarsboom nie. Hierdie standpunt van Luther en Calvyn, dat daar 'n rangorde van dogmatiese uitsprake bestaan, word deesdae algemeen in die Protestantse wêreld as die geldige standpunt aanvaar (Engelbrecht 1978:288; Schlink 1983:697-698; Balke 1990: 267; Van Genderen 1993:647; Nijenhuis 1994:37). Hierdie standpunt kom daarop neer dat ten spyte daarvan dat eenheid nie maklik in leer bereik kan word nie, dít nie mag verhoed dat kerke alles moontlik moet doen om te verseker dat daar konsensus in terme van die belydenis oor Jesus Christus sal kom nie. Veral in ons dae, waar die "heerskappy" van die historiese kritiek dit besonder bemoeilik om eenstemmigheid oor leersake te kry, moet ons nogtans poog om konsensus te bereik oor die belangrike sake, aangesien kerklike eenheid tot ' $n$ baie groot mate van eenheid in leer afhang (Pannenberg 1977:252-258; Kühn 1980:208-211). Die NHKA en die HKSA sal ook moet begin om 
werklike leergesprekke met mekaar te voer. Indien daar nie konsensus oor sake soos die "voorvadergeloof" kan kom nie, sal daar geen vordering in kerkeenheid kom nie.

\subsubsection{Kerklike eenheid kry sigbare gestalte deur één te wees in teologie}

In die kerk vind geloof uiting in belydenisse. Belydenisse word in leerstellings gepresiseer, en leerstellings word weer in die teologie verder uitgewerk, verdedig en begrond. Sigbare kerklike eenheid kan daarom realiseer wanneer daar eenheid in teologie is. Die vraag wat nou gevra moet word is: bestaan daar én teologie in die NHKA en die HKSA? Nog meer: kan daar en mag daar één teologie tussen die twee kerke bestaan? Daar is goeie rede om te vermoed dat daar nie eenheid in teologie bestaan nie. Ten spyte daarvan dat die HKSA 'n produk is van die Westers-Calvinistiese belydenis- en leertradisie, is dit ook 'n Afrika-kerk. Die Afrika-dimensie bepaal heel duidelik in 'n groot mate die aard en karakter van die teologie van die HKSA. Dit is byvoorbeeld duidelik dat daar in die HKSA met 'n tipiese Afrika holisme gewerk word, terwyl die NHKA weer werk met 'n Lutherse twee-ryke-leer, getemper deur die Calvinistiese koningsheerskappy-van-Christusteorie (vgl Mpanza 1995:45-48; Van Wyk 1996b). Daar bestaan ook goeie redes hoekom daar nie één teologie kan en mag wees nie. Die belangrikste rede is dat dit die Afrikaniseringsproses in die HKSA sal dwarsboom. Anders gesê: één teologie kom voort uit ' $n$ imperialistiese gees, waarvoor daar nie plek in die "Afrika-renaissance" (Mbeki 1998) is nie.

Ten spyte daarvan dat daar ruimte moet wees vir die "inheemswording" van die teologie in Afrika, mag hierdie teologie nie ontaard in 'n "Afrika-teologie" nie. Ook inheemse teologie moet Christelike teologie wees. Ook die HKSA-teologie moet belydenisgebonde teologie wees, of so nie word die katolisiteit van die kerk ondergrawe. Ten spyte van ruimte vir die kulturele eie-aardigheid in die teologie, mó́t daar nogtans eenheid in die teologie wees, indien dit die waarheid van die evangelie as sentrum het.

\subsubsection{Kerklike eenheid kry sigbare gestalte deur één te wees in konfessie}

Ons het gesê dat teologie 'n kulturele en 'n konfessionele kleed het. Die kulturele kleed bring verskeidenheid en pluraliteit mee. Dit kan selfs ook onenigheid en verskeurdheid meebring. Om hierdie rede moet die konfessionele onderkleed altyd aangehou word. Dit 
moet aangehou word, sodat die eenheid in die waarheid verseker kan word. Ywer vir die eie konfessie is daarom die eerste stap ten opsigte van kerklike eenheid. Karl Barth het hierdie aspek sterk beklemtoon. Die rasionaal agter hierdie argument is dat Barth meen dat indien eenheid, eenheid in geloof, belydenis en leer is, eenheid primêr en hoofsaaklik gestalte kry in die plaaslike gemeente. Slegs in die plaaslike gemeente kan daar sprake wees van ware eenheid, naamlik eenheid in gehoorsaamheid en eenheid in die hoor van die stem van Christus. Die stem van Christus hoor ons deur die prediking wat konfessioneel gekleurd is, indien dit belydenisgetroue prediking is. Die ywer vir die eie konfessie is daarom vir Barth nie die ondergrawing van kerklike eenheid nie, maar juis die versterking daarvan. Daar is egter een voorwaarde: ywer vir die konfessie moet daar wees op grond van die boodskap van Jesus Christus soos ons dit in die Bybel verneem het. Indien hierdie ywer eintlik oor ander sake soos politiek, geskiedenis, kultuur ensovoorts gaan, word die eenheid van die kerk nie gedien nie (Barth 1986:223-232).

\subsubsection{Kerklike eenheid kry sigbare gestalte deur één te wees in gesindheid}

Die soeke na eenheid kan nooit met die bedoeling wees om eenheid te skep nie, aangesien die kerk in wese één is. Die bedoeling kan hoogstens wees om die wesenlike eenheid, die God gegewe eenheid, binne die Christendom te ontdek en om op grond daarvan onnodige verkeerdhede uit die weg te ruim, sodat die God gegewe eenheid in die wêreld sigbaar kan word. Die etiese opdrag van die kerk kan dus net uit die volgende twee aspekte bestaan: die waarneming van die eenheid te midde van 'n verdeelde Christendom, en die soeke na weë om hierdie eenheid tot uitdrukking te bring sodat die kerk 'n goeie afbeelding kan word van die eenheid wat daar bestaan tussen Vader, Seun en Heilige Gees. Hierin kan geslaag word, wanneer daar 'n wil is om verkeerdhede uit die weg te ruim en om daarom af te sien van alle reghêery, liefdeloosheid en selftevredenheid (Schlink 1983:684-685).

\section{GEEN EENHEID IN ORGANISASIE NIE?}

In die vorige gedeelte is daar geargumenteer dat die reeds bestaande kerklike eenheid sigbare gestalte kry deur één te wees in geloof, belydenis, leer, teologie, konfessie en gesindheid. Dít alles beteken dat eenheid "geestelike eenheid" is, en dat dit nie afge- 
dwing of georganiseer kan word nie. Bemoeienisse om eenheid kan hoogstens getuienis aflê van die eenheid van die liggaam van Christus (Ebeling 1979:474). Dít mag alles goed en wel wees, maar die vraag bly egter: kán daar nie en móét daar uiteindelik nie ook georganiseerde eenheid wees nie?

Ons het by afdeling 2 gesien dat Cyprianus en Augustinus geoordeel het dat organisatoriese eenheid noodsaaklik en gebiedend is. 'n Mens sou seker met goeie argumente met hierdie twee kerkvaders kon saamstem. Die realiteit is egter dat organisatoriese eenheid slegs onder 'n episkopale stelsel verwesenlik kon word, wat nou nie juis die ideale kerkregtelike stelsel is nie. Die geskiedenis het bewys dat hierdie stelsel nie in terme van die intensies daarvan kan slaag nie (Ebeling 1979:375). 'n Mens sou vandag in elk geval nie meer van die eenheid van die Christendom kon praat nie. Van georganiseerde eenheid van die één kerk van Christus, dit is die liggaam van Christus, kan daar vandag nie meer sprake wees nie. Sedert die Reformasie kan eenheid nie meer organisatories, institusioneel of sosiologies bedink word nie. Die Reformasie het die institusionele eenheid van die Christendom finaal vernietig (Pannenberg 1977:254-267; McGrath 1994: 419). In die lig van hierdie realiteite het die Protestantisme besef dat eenheid nie primêr in terme van organisasie en struktuur bedink kan word nie. Sinvolle eenheid kan nog net bedink word in terme van waarheid en katolisiteit (Engelbrecht 1978:287). Dit het dus geen sin meer om die vraag na eenheid toe te spits op die vraag na die eenheid van organisasie nie. In die lig hiervan het Barth (1986:217) ingesien dat dit net sin kan hê om die vraagstelling toe te spits op die eenheid in Christus. Eenheid kan en moet nie bedink word in terme van een struktuur of organisasie nie waarvan iemand (die pous) of iets ('n regeervergadering) die hoof is nie, maar in terme van geloofsgemeenskappe waarvan Christus die hoof is. Eenheid is dus wel 'n moontlikheid tussen verskillende kerke wat die hoofskap van Christus gesamentlik erken en eerbiedig. Op hierdie wyse kan eenheid tot stand kom deur 'n gesamentlike gehoorsaamheid aan die Heer en Hoof van die kerk (Smidt 1972:14-15). Hierdie argument verhoed dat mense eenheid ten alle koste wil organiseer en afgedwing. Dit kan hopelik meebring dat mense sal poog om die verskeurdhede op te los deur hulle menslike hooghartighede te staak, en te begin om die, deur selfsug gedrewe mure, af te breek (Krötke 1994:96). 
Hierdie standpunt bly vir die meeste van ons ongemaklik. Ons kan maar nie aanvaar dat eenheid slegs geestelik kan wees nie. Ons wil hê dat dit ook institutêr moet wees (Van Genderen 1993:645). Dit is te verstane dat mense sal aanhou om te meen dat die geloofseenheid ook organisatories gestalte moet kry. Mense wil graag eenheid onder mekaar beleef en ervaar. Hulle het 'n hartstog na eensgesindheid en samewerking. Hierdie menslike gevoelens en emosies mag egter nie ons denke oor kerklike eenheid oorheers nie. Ons mag nie toelaat dat ons in 'n denkproses ingedwing word waar eenheid net as organisatoriese eenheid bedink word nie. Afgesien van die feit dat dit in die verlede nie kon slaag nie, en vandag nie meer in groter kontekste haalbaar is nie, is daar ook talle teologiese besware wat geopper kan word. Daar moet byvoorbeeld ingesien word dat één organisasie geen waarborg vir eenheid is nie (Balke 1990:262). Een organisasie is verder ook geen waarborg dat eenheid bewaar sal kan word nie (Van Selms 1952:141-143). Kerklike eenheid kan ook nie deur 'n cogite intrare afgedwing word nie. Met ander woorde; kerkeenheid word nie deur politieke of sosiale druk geskep nie en dit word ook nie deur allerlei samewerkingsooreenkomste bevorder nie. Die eenheid van die gemeente van Jesus Christus is nie identies met 'n uiterlik bevredigende saamleef of samewerking van verskillende kerke nie. Geen ekumeniese liggaam of konvent of verenigingstruktuur maak die kerke werklik één nie, aangesien die eenheid nie in die struktuur lê nie, maar in die geloof (Barth 1960:757). Ons moet besef dat selfs Rooms-Katolieke deesdae die volgende sê:

The unity of the church has nothing to do with the mythological magic of the number one and the intrinsic fascination of oneness. The unity of the church is not simply a natural entity, is not simply moral unanimity and harmony, is not just sociological conformity and uiniformity. To judge it by externals ... is to misunderstood it completely. The unity of the church is a spiritual unity.

(Küng 1976:273) 
Teoloë binne ons teologiese tradisie het die volgende konsekwensies uit hierdie oortuiging getrek. Emil Brunner (1964:153-155) meen dat ons onsself daarvan bevry om ten alle koste net een kerklike struktuur te wil vorm. Omdat eenheid, eenheid in geloof is, moet die veelheid van kerke nie vir ons ' $n$ verleentheid wees nie. Ben Engelbrecht (1978:289) kon op voetspoor van Brunner konsekwent verder argumenteer dat aangesien eenheid net in geloof en leer bestaan, daar ' $n$ veelheid van kerke binne een volk en 'n veelheid van kerke onder verskillende volke kan bestaan, en dat hierdie veelheid van kerke nie sondige verskeurdheid hoef te wees nie. Die vraag is nou weer: is hierdie konsekwensies werklik verantwoordbaar? Laat die Reformatoriese denke oor eenheid nie ruimte vir ander aksente nie? Kan 'n mens werklik die argument voer dat omdat kerkeenheid eintlik geloofseenheid is, die veelheid van kerke die wenslike is? Ek meen nie dat hierdie konklusie geldig is nie. Omdat kerklike eenheid 'n gegewe is, moet ons iets van hierdie onsigbare eenheid sigbare gestalte gee. In ons spesifieke geval moet ons ook nie eenwording as 'n teoretiese en praktiese onmoontlikheid beskou nie. Die ruimte moet gelaat word dat eenwording in die verre toekoms wel 'n opsie kan wees. Regdeur die kerklike geskiedenis was daar altyd geslaagde verenigingspogings (Kühn 1980:202). Ek meen dat ons Schleiermacher (1984:305-306) se oortuiging moet deel dat geen volks- of taalgrense die soeke na kerklike eenheid mag verhinder nie. Ons moet daaraan vashou dat die Heilige Gees alle grense van watter aard ook kan oorwin. Menslik gesproke moet die moontlikheid van ' $n$ kerkvereniging in die toekoms ook oopgehou word. Ou politieke, maatskaplike en kulturele redes wat kerke uitmekaar gehou het, kan verdwyn en dan behoort daar opnuut na die wenslikheid van strukturele eenheid gekyk te word (Küng 1976:276-279). 'n Mens sê hierdie dinge met die wete dat sigbare eenheid 'n eskatologiese saak is (Elert 1988:438). Op hierdie aarde sal ons nie absolute sigbare organisatoriese eenheid kan skep nie. Binne Duits-Lutherse geledere blyk dit soms of eenheid tussen die kerke uit die ou Oos-Duitsland en die die ou Wes-Duitsland 'n onmoontlikheid is (vgl Krötke 1994 vir insae in hierdie stryd). Hoeveel te meer sal ons nie met ons verskillende tale en kulture, probleme hê om van die twee kerke één te maak nie? Een organisasie tussen die NHKA en die HKSA is op hierdie stadium beslis nie moontlik en of wenslik nie. Maar, dít beteken nie dat die geestelike eenheid wat reeds bestaan, nie sigbare gestalte mag kry nie. Ek meen dat die geestelike eenheid wel sigbare gestalte móét kry. 


\section{SIGBARE GESTALTEGEWING VAN DIE GEESTELIKE EENHEID}

Voordat ons iets oor die gestaltes van ekumeniese eenheid sê, moet ons mekaar net weer daaraan herinner dat sigbare eenheid primêr in die plaaslike gemeente gestalte aanneem. Die rede: dít is die plek waar die evangelie verkondig word, geglo word en gehoorsaam word. In kort: dít is primêr waar die kerk kerk is. Om hierdie rede is eenheid binne die gemeente baie belangriker as enige vorm of gestalte van ekumeniese eenheid (Ebeling 1979:375). Die eenheid wat binne 'n gemeente gestalte moet kry, het niks te make met die assosiasiedrif van mense nie. Eenheid in 'n gemeente behoort om geloofseenheid te handel en mag nie uitdrukking wees van 'n kultuur-antropologiese behoefte nie, want juis dít verwoes uiteindelik die eenheid in 'n gemeente (Weber 1972:610-611). Geloofseenheid maak dit juis moontlik dat verskillende mense van verskillende agtergronde, persoonlikhede en sosiaal-politieke aspirasies in een gemeente saam kan lewe en werk. Geloofseenheid bewaar gemeentes van uniformiteit en onbeperkte pluralisme (Moltmann 1975:368-371). Eenheid in 'n gemeente behoort veral rondom die Nagmaalstafel tot openbaring te kom (Van Genderen 1993:647). Daar behoort daarom 'n oop uitnodiging na die Nagmaal te wees en al die lidmate moet die gevoel kry dat daar vir hulle plek en ruimte aan die tafel van die Here is. Indien dit nie só is nie, moet daar aan die eenheid binne die gemeente gewerk gaan word. Wanneer daar gewerk word aan eenheid binne gemeentes, sal eenheid tussen gemeentes makliker gerealiseer word. En dít is waar eenheid volgende gestalte moet aanneem. Gemeentes is nie eilande nie. Gesamentlik vorm hulle (die) kerk. Net saam met ander gemeentes kan 'n gemeente se roeping ten volle uitgelewe word. Daarom móét daar eenheid tussen gemeentes wees, sodat hulle hulle roeping gestand kan doen. Sigbare eenheid mag nou ook nie weer tot eenheid tussen gemeentes beperk word nie. Eenheid moet ook tussen kerke gestalte aanneem. Die rede: eenheid is nie net 'n geloofswerklikheid nie, maar ook 'n ekumeniese doelwit (Pannenberg 1977: 200-210). Net soos wat gemeentes nie op hulle eie aan hulle roeping kan voldoen nie, net só kan kerke ook nie op hulle eie in alles aan die Heer van die kerk gehoorsaam wees nie. Kerke móét met ander kerke saamwerk, ter wille van gehoorsaamheid en gesamentlike diakonia, martyria en koinonia (Lohse 1978:244). Wanneer kerke met mekaar saamwerk, mót die gesprek oor eenheid vroeër of later ter tafel geneem 
word (Schlink 1983:696). Ter wille van hulle samewerking móét daar eenheidsgestaltes geskep word. Ten spyte daarvan dat sigbare eenheid tussen kerke wesenlik belangrik is, moet ons altyd besef dat hierdie gestalte van eenheid hoogstens as 'n proses verstaan kan word. Dit is ' $n$ weg wat bewandel moet word. Dit is daarom dwaas om vooraf te wil sê hoe eenheid daar moet uitsien. Uit die samewerking moet ' $n$ gestalte van eenheid groei. Ons moet dus nie vasgevang raak in statiese denke nie. Ons moet ruimte laat vir ontwikkeling en andersheid in sake eenheid tussen kerke (Ott 1981:433-435). Maar, die vraag is nou nog steeds: watter gestaltes kan en moet die eenheid tussen die twee kerke aanneem, sodat daar van ware ekumeniese eenheid sprake kan wees?

\section{GESTALTES VAN EKUMENIESE EENHEID}

Ekumeniese eenheid neem verskillende gestaltes aan. Die eerste gestalte wat vir hierdie gesprek van wesenlike belang is, is wat ons liturgiese eenheid (Schlink 1983:684, 706707) kan noem. Liturgiese eenheid het betrekking op verskeie aspekte wat die erediens direk en indirek raak. In die eerste instansie gaan dit om toeganklikheid van die eredienste. Indien daar na ekumeniese eenheid gestrewe word, behoort die eredienste vir mekaar oop te wees (Van Wyk 1994; Van Staden 1994a; 1994b). Op geen manier kan daar bely word dat die kerk in wese één is, maar lidmate van die ander kerk word toegang tot eredienste geweier nie. Kerke wat aan die geloofseenheid sigbare ekumeniese gestalte wil gee, se deure móét vir mekaar oop wees. Sigbare liturgiese eenheid moet in die tweede instansie in gesamentlike eredienste tot uitdrukking kan kom. Dit mag egter nie onder dwang geskied nie. Dit moet spontaan gebeur. Dit moet uitdrukking wees van die behoefte en begeerte van die lidmate van die betrokke kerke om die Here gesamentlik te aanbid. Aan die ander kant moet lidmate ook weet dat die sigbaarmaking van die gekende eenheid in erediens en lewe, die wil van God is (Schlink 1983:701). 'n Derde gestalte van liturgiese eenheid is waar kerke mekaar se doop erken (Weber 1972:612). Met die erkenning van mekaar se doop, kry die geloof in die één onsigbare kerk sigbare gestalte. 'n Vierde gestalte van liturgiese eenheid waarna verwys moet word, is die eenheid rondom die Nagmaalstafel. Nagmaal is die sakrament van die eenheid (Pannenberg 1977:286-292; Kühn 1980:205-207). Nêrens anders kan die eenheid in die liggaam en bloed van Christus beter gestalte aanneem as juis aan die Nagmaalstafel nie. Daar 
behoort daarom 'n oop uitnodiging na die Nagmaalstafel te wees aan lidmate van kerke wat met jou eie kerk in 'n ekumeniese verhouding staan. 'n Geslote Nagmaalstafel vir gelowiges met dieselfde belydenis verraai werklik 'n leerdwaling in die ekklesiologie. Omdat die Nagmaal by uitstek die simbool van eenheid is, word die bedienaars van die Nagmaal onwillekeurig by hierdie besprekingspunt betrek. Eenheid rondom die tafel is net moontlik, wanneer daar erkenning van die ampsdraers is wat die Nagmaal bedien (Pannenberg 1977:268-285; 1993:435-441). Die erkenning van die ampte is daarom die vyfde gestalte van liturgiese eenheid wat ter sprake gebring moet word. Die rede vir hierdie stelling loop soos volg: die "kerk" is die gemeente wat in die erediens versamel is en wat deur 'n gelegitimeerde bedienaar van die Woord en sakrament voorgegaan word. Die gelegitimeerdheid van die dienaar van die Woord en die sakrament, is 'n heenwysing na die eenheid met die apostels, en só na die apostolisiteit van die kerk. Deur 'n ander kerk se Nagmaalbedienaars te erken; met ander woorde, om toe te laat dat die eie lidmate Nagmaal van hierdie predikant ontvang, is daarom die tot uiting bring van die eenheid in apostolisiteit. Deur deel te hê aan die ander kerk se handopleggingseremonie tydens die ordening van 'n predikant, deur met hierdie predikant kansel te ruil en saam met hom of haar Nagmaal te bedien, is by uitstek 'n bevestiging dat die deelnemende kerke hulle eenheid in apostolisiteit tot uiting wil bring (Van Aarde 1989:470-474).

Die tweede gestalte van ekumeniese eenheid waarvoor ek wil pleit, is die vorming van 'n Hervormde ekumeniese sinode. 'n Gesamentlike sinode kan gestalte gee aan eenheid soos ons dit tot hiertoe verduidelik het. Eenheid, het ons gesê, kan nie organisatories geskep word nie. Dit kom dáár tot stand waar daar na die Woord geluister word. Hierdie luister kan nie beperk word tot die luister van die eie kerk nie, maar sluit die luister van ander kerke in. Die gesamentlike luister na die Woord, en die luister na 'n ander se luister, bevorder kerkeenheid (Barth 1960:764). 'n Hervormde ekumeniese sinode is die plek waar daar gesamentlik na die Woord en na mekaar se hoor van die Woord geluister kan word. Dit is daarom die logiese kerkordelike keuse vir die skep en die bewaring van eenheid. Die eenheid tussen gemeentes en kerke kan PresbiteriaalSinodaal net deur 'n sinode verseker word (Weber 1972:614-618; Heyns 1988:378). Op 'n sinode kan daar eenheid in geloof, belydenis, leer en teologie tot stand kom. Op 'n sinode kan leerverskille bygelê word en leerdwalings veroordeel word. Sinodaal kan die 
kommer oor voorvaderaanbidding' en "burgerlike godsdiens" uit die weg geruim word. Sinodaal kan daar 'n eenstemmige en eendragtige apostolêre visie ontwikkel word, wat absoluut noodsaaklik is vir die gehoorsaamheid van beide kerke aan die roeping wat hulle ontvang het om die evangelie in Afrika in te dra. Ek neem vrymoedigheid om te pleit vir 'n Hervormde Ekumeniese Sinode, aangesien dít die onafhanklikheid van beide kerke sal verseker, maar hulle tog ook weer sal laat saamdink en saamwerk op terreine wat weselik belangrik is vir die voortgang van die evangelie. Op hierdie wyse kan eenheid struktuur en gestalte kry, sonder die (noodwendige) gevaar van kerkskeuring, wat 'n kerkvereniging altyd meebring.

Die derde gestalte van ekumeniese eenheid waaroor daar innovatories nagedink moet word, is die eenheid in opleiding. Ten spyte van al die historiese, maatskaplike, ekonomiese, politieke, kulturele, opvoedkundige en kerkregtelike argumente ten gunste van aparte opleidings vir die studente van die NHKA en die HKSA, het die tyd aangebreek dat daar na maniere gesoek moet word om groter eenheid in opleiding te bewerkstellig. Afgesien van al die strategiese, finansiële en strukturele argumente wat geopper kan word, is die belangrikste teologiese rede ten gunste van groter eenheid in opleiding dat eenheid in geloof, belydenis en leer na groter eenheid in die teologie mót uitkring. Groter samewerking en integrering van die HTO en die teologiese opleiding aan die Universiteit van Pretoria móét daarom op een of ander manier bedink word.

Ekumeniese eenheid kan en moet in ons dae in die vierde instansie tot uiting kom in getuienis of profetiese roeping. Die kerklike stryd het die afgelope aantal dekades wêreldwyd, en veral sedert die 1994 verkiesing in Suid-Afrika, dramaties verander. Kerke kan net nie meer die luuksheid bekostig om mekaar te beveg nie. Hulle moet in ons dae saamstaan en saamwerk. Gesamentlike en gemeenskaplike getuienis teenoor die wêreld het onontbeerlik geraak (Ott 1981:422-427; Heyns 1988:377-378). Die veranderende politieke opset in ons land en die bedreiging van die Islam maak hierdie gestalte van eenheid 'n dringende noodsaaklikheid. As dit nou werklik moet, kan ons apart marsjeer, maar ons móét vandag verenig slaan (Brunner 1964:154). Om dít te kan doen moet daar gesamentlike besinning en navorsing wees. Rade en sinodale kommissies, konvente en ekumeniese sinodes moet gesamentlik navorsing doen en besin oor veral maatskaplike probleme. Die dae is verby dat "wit kerke" alleen kan navorsing doen en getuienis lewer. 
Ons maatskaplike werklikhede het só verander, dat "wit" en "swart kerke" sal moet saamwerk om probleme en hulle agtergronde te verstaan, en om dan op grond van hierdie verstaan, verantwoordelik teenoor die gemeenskap en die owerhede te getuig (kyk vir volledigheid na Van Wyk 1996a, 1996b).

Ekumeniese eenheid moet in die vyfde plek gestalte aanneem as diens en liefde. Niemand minder nie as Calvyn (IV, 2.5) het dit verkondig, dat eenheid wat eenheid in leer is, noodwendig in die eenheid van liefde en diens moet uitmond. Hierin word hy gevolg deur Lutherane (Kühn 1980:211-214) en Calviniste (Heyns 1988:378). Calviniste begrond hierdie oortuiging vanuit die derde kenteken van die ware kerk. Die ware kerk kan volgens Calvinistiese oortuiging nie net die evangelie reg verkondig en die sakramente suiwer bedien nie, maar moet ook die liefdesgebod uitlewe. Daar moet dus ook oorgegryp word na die tweede tafel van die wet. Ware kerkwees handel nie net om ware geloof nie, maar ook om ware liefde (Goebel 1990). Waar daar dus uit die liefde gelewe en gehandel word, sal die eenheid tussen kerke noodwendig groei. Prakties moet hierdie oortuiging vir my gestalte aanneem in (a) die tussenkerklike diakonaat, maar (b) ook in die missionêre diakonaat.

\section{- Die tussenkerklike diakonaat}

Met tussenkerklike diakonaat bedoel ons: barmhartigheidswerk oor die grense van die eie kerk heen. Maar, met tussenkerklike diakonaat word daar veel meer bedoel as net barmhartigheidswerk. Hier word bedoel: die ganse ondersteuning en bystand aan 'n ander kerk moet die liefdesgebod transpareer. Om dít reg te kry, moet die totale verhouding tussen die twee kerke menslik raak en menslikheid uitstraal. Die evangelie word nie gedien om maar net 'n finansiële subsidie maandeliks koud en klinies aan mense uit te betaal nie. Daar moet met hierdie mense as mense gewerk word. Hulle moet in hulle menslike stryd en worsteling ondersteun word. Diakonaat gaan nie om die gee van geld deur middel van 'n amptenaar nie, maar om die totale liefde en deernis van mense vir ander mense ter wille van die evangelie. 


\section{- Die missionêre diakonaat}

Diakonaat, wat ten diepste barmhartigheidswerk is, maar wat ook neerkom op menslike ondersteuning, hulp en bystand, kan nie net beoefen word tussen reeds bestaande kerke nie. Diakonaat moet ook op die sendingveld beoefen word. Mense wat nie lidmate is van kerke is nie, kan en moet ook diakonal bedien word. Hoekom? Omdat die stryd om die siel van Afrika in 'n groot mate op hierdie terrein gewen of verloor gaan word. Suiwer Woordbediening, sonder daadwerklike diakonaat, het nie in Afrika 'n kans om suksesvol te wees nie. Afrika wil gehelp word met kos vir vandag. Maar Afrika wil ook gehelp word om kos vir more te produseer. Afrika het gemeenskapsdiens nodig, en wie dít aan gemeenskappe kan bied, het ook 'n kans om hulle vir die evangelie en die kerk te wen. Hierdie noodsaaklike missionêre diakonaat of verkondigende diakonaat, kan eintlik net gesamentlik gedoen word. Nét as die NHKA en die HKSA hande vat in hierdie verantwoordelikheid, is daar ' $n$ kans op sukses. Eenheid in diens en liefde mag dus nie 'n droom en ideaal wees nie, dit is plig en verantwoordelikheid. Hierdie verantwoordelikheid het niks op dees aarde met sekulêre ekumenisme (Van Genderen 1993:644) te make nie. Dit gaan om gehoorsaamheid aan die evangelie (Matt 25:31-46). Indien ons nie gehoorsaam wil wees nie, sal die Moslems, wat meesters is van die missionêre diakonaat, eenvoudig ons plek in Afrika oorneem.

Ekumeniese eenheid is van wesenlike belang vir die voortgang van die evangelie in ons wêrelddeel. Die klagte deur die eeue heen, dat die verskeurdheid van die kerk tot die mislukkings op die sendingterrein bydra, is 'n geldige klagte. Trouens, dit is selfs 'n geldige aanklag. Dit is eenvoudig waar dat onenigheid onder Christene en hulle kerke, in 'n groot mate die oorsaak is van die ongeloofwaardigheid van die evangelie op die sendingveld (Küng 1976:270-271; Pannenberg 1977:201; Barth 1986:215). Indien ons eerlik wil wees, sal ons in die NHKA en die HKSA dit nie kan ontken nie dat ons onenigheid ook in 'n groot mate vir ons apostolêre mislukkings verantwoordelik is. As ons groter sukses op die sendingveld wil hê, sal ons groter eenheid moet openbaar.

Eenheid tussen die NHKA en die HKSA sal net groei, as daar 'n groei in die heiligheid van die twee kerke is. Heiligheid beteken: om nie van die wêreld te wees nie, en om nie soos die wêreld te wees nie. Konkreet beteken dit dat die kerke nie as verlengstukke van samelewingsverskynsels, óf as religieuse legitimeerders van samelewing- 
sideale mag funksioneer nie. Kerke wat in hulle blote bestaan, religieuse legitimeerders van samelewingsverskynsels en of samelewingsideale wil wees, ondergrawe die eenheid van die kerk. Die kerk wat die evangelie ten alle koste in 'n apartheidskleed wil toedraai, en die kerk wat die evangelie ten alle koste met die wa van "nationbuilding" wil vervoer, sal skuld moet dra vir die verwoesting van die eenheid van die kerk. Ons sal dus in beide kerke 'n ekklesiologie moet ontwikkel wat dit vir ons moontlik gaan maak om groter distansie teenoor ons eie gemeenskappe en hulle politieke ideale te handhaaf. Deur verlengstukke en of krone van gemeenskappe te wees, verhoed uitlewing van die heiligheid van die kerk. Deur anders as die wêreld te wees, deur ander gesindhede te openbaar, deur ander ideale te koester, deur ander prioriteite in die lewe te hê, sal ons in staat stel om die heilige eenheid van die kerk na te jaag, soos wat Christus van ons verwag.

\section{SAMEVATTING}

Ten spyte daarvan dat daar in sekere kringe van die twee kerke 'n gevoel van ongemak met, en selfs ' $n$ gevoel van weersin in mekaar is, is daar gelukkig ook ' $n$ groeiende besef van interafhanklikheid en is broederskap aan die ontwikkel. Ons roeping op hierdie stadium is om opnuut die hand na mekaar uit te steek en om gesamentlik te probeer regstel wat verkeerd is. Ons roeping is nie om die rug op mekaar te keer nie. Ons moet mekaar egter as selfstandige kerke respekteer en nie op hierdie stadium probeer om 'n eenheidsmodel van een organisasie op mekaar af te dwing nie. Wanneer dít die doelwit van eenheidsgesprekke word, word daar in die hande gespeel van hulle wat hulle beywer vir die "opdoeking" van die hele verbintenis tussen die NHKA en die HKSA. Ek pleit vir eenheid in geloof, belydenis, leer en teologie - en dít kan nie georganiseer word nie. Ek vra vir die nugtere besef van die groot verskille in taal, kultuur en mentaliteit, sonder om dit as skanse te misbruik om mense ten alle koste uit mekaar te hou. Maar, ek pleit ook vir ekumeniese eenheid tussen die twee kerke; vir samewerking op alle gebiede; vir gestaltegewing van die eenheid wat ons reeds in Christus het.

\section{Literatuurverwysings}

Balke, W 1990. De eigenschappen van de kerk, in Van't Spijker, W et al (reds), De Kerk, 259-282, (ed). Kampen: Goudriaan. 
Barth, K 1960. Die Kirchliche Dogmatik, Band IV,I. Zürich: EVZ.

- [1957] 1986. Die Kirche und die Kirchen (1935), in Theologische Fragen und Antworten, Band 3, 214-232. 2.Aufl. Zürich: TVZ.

Botha, C J 1979. Calvyn se siening oor die eenheid van die kerk, in Meiring \& Lederle 1979:32-43.

Brunner, E [1960] 1964. Dogmatik, Band III. Zürich: Zwingli-Verlag.

Calvyn, J [1559] 1991. Institusie van die Christelike Godsdiens, Bande 1-4. Potchefstroom: CJBF.

Castro, E 1992. A passion for unity: Essays on ecumenical hopes and challenges. Geneva: WCC Publications.

Ebeling, G 1979. Dogmatik des christlichen Glaubens, Band IIl. Tübingen: Mohr.

Elert, W [1940] 1988. Der christliche Glaube: Grundlinien der Lutherischen Dogmatik. 6. Aufl. Erlangen: Martin-Luther-Verlag.

Engelbrecht, B J 1978. Teologie in die kerk. Pretoria: HAUM.

Goebel, H T 1990. Notae ecclesiae: Zum Problem der Unterscheidung der wahren Kirche von der falschen Kirche. EvTh 50, 222-241.

Ganoczy, A 1968. Ecclesia Ministrans: Dienende Kirche und kirchlicher Dienst bei Calvin. Freiburg: Herder.

Heyns, J A 1988. Dogmatiek. Goodwood: NGK.

John, E C 1994. Einheit und Vielfalt der Kirche: Eine indische Perspektive. ZfM 20, 87 95.

Jonker, W D 1987. Die eenheid van die kerk - noodsaak of luukse? UPTS 3, 35-44.

Käsemann, E 1970. Begründet der neutestamentliche Kanon die Einheit der Kirche?, in Das Neue Testament als Kanon: Dokumentation und kritische Analyse zu gegenwärtigen Diskussion. Göttingen: Vandenhoeck.

Krötke, W 1994 Die Chancen und die Schmerzen der Einheit: Theologische und pragmatische Überlegungen zur Einheit der evangelischen Kirchen in Deutschland. ZfM 20, 96-106

Kühn, U 1980. Kirche. Gütersloh: Mohn. (HST 10.)

Küng, H [1967] 1976. The church. London: Search Press.

Lohse, B 1978. Epochen der Dogmengeschichte. Stuttgart: Kreuz 
Lohse, B 1988. Die Einheit der Kirche bei Luther, in Evangelium in der Geschichte: Studien zu Luther und der Reformation, 300-314. Gottingen: Vandenhoeck.

- 1995. Luthers Theologie in ihrer historischen Entwicklung und in ihrem systematischen Zusammenhang. Gottingen: Vandenhoeck.

Lohse, E 1973. Die Einheit der Kirche nach dem Neuen Testament, in Die Einheit des Neuen Testaments, 334-345. Göttingen: Vandenhoeck.

Luther, M 1883vv. Kritische Gesamtausgabe (Weimarer Ausgabe $=$ WA). Weimar: Herman Bohlau.

Mbeki, T 1998. Africa - the time has come. Selected speeches. Cape Town: Tafelberg.

McGrath, A 1994. Christian Theology: An introduction. Oxford: Blackwell.

Meiring, P \& Lederle, H (red) 1979. Die eenheid van die kerk. Kaapstad: Tafelberg.

Moltmann, J 1975. Kirche in der Kraft des Geistes. München: Kaiser.

Mpanza, S P 1995. The role of leadership in the vitalization of the Hervormde Kerk in Suidelike Afrika: Developing post apartheid leadership styles for church vitaliztion in a poor African community. Unpublished MTh dissertation, University of the Western Cape.

Nederduitsch Hervormde Kerk van Afrika 1997. Kerkorde van die Nederduitsch Hervormde Kerk van Afrika.

Nijenhuis, W 1959. Calvinus Oecumenicus: Calvijn en de eenheid der kerk in het licht van zijn briefwisseling. 'S-Gravenhage: Martinus Nijhoff.

- 1994. Church unity in Luther and Calvin, in Ecclesia Reformata: Studies on the Reformation, Vol II, Deel XVI, 24-47. Leiden: Brill.

Ott, H 1981. Die Antwort des Glaubens. Stuttgart: Kreuz.

Pannenberg, W 1972. Das Glaubensbekenntnis ausgelegt und verantwortet vor den Fragen der Gegenwart. Hamburg: Siebenstern. (ST 165.)

- 1977. Ethik und Ekklesiologie. Göttingen: Vandenhoeck.

- 1993. Systematische Theologie, Band III. Göttingen: Vandenhoeck.

Pelser, G M M 1994. Enkele opmerkings oor die wese van die kerk. HTS 50, 311-329.

- 1995. Die kerk in die Nuwe Testament. HTS 51, 645-676.

Schleiermacher, F [1821/22] 1984. Der christliche Glaube, Band 2. Studienausgabe. Hrsg v Peiter, H. Berlin: De Gruyter. 
Schlink, E 1983. Ökumenische Dogmatik. Göttingen: Vandenhoeck.

Slenczka, R 1973. Die Lehre trennt - aber verbindet das Dienen? KuD 19, 125-149.

Smidt, U 1972. Johannes Calvin und die Kirche: Ein Lesebuch mit Texten und Themen. Stuttgart: Evangelisches Verlagswerk.

Strijdom, J 1995. Diversiteit van die begin af: 'n Vergelyking van Mack en Crossan se konstruksies van die vroegste Christendomme (ca 30-70 nC). HTS 51, 108-133.

Tetz, M 1984. Athanasius und die Einheit der Kirche: Zur ökumenischen Bedeutung eines Kirchenvaters. ZThK 81, 196-219.

Theissen, G 1994. Die Einheit der Kirche: Kohärenz und Differenz im Urchristentum. ZfM 20, 70-86.

Van Aarde, A G 1987. Gedagtes oor die begin van die kerk: 'n Geskiedenis van versoenende verskeidenheid. HTS 43, 325-351.

- 1989. 'n Nuwe-Testamentiese begronding van die eenheid van die kerk en die eis om kerkeenheid vandag. HTS 45, 461-475.

- 1995. Die menslikheid van en die verskeidenheid in die kerk. HTS 51, 865-875.

Van der Watt, P B 1987. Eenheid in die Afrikaanse kerke. UPTS 3, 1-12.

Van Genderen, J \& Velema, W H [1992] 1993. Beknopte Gereformeerde Dogmatiek. 2e Druk. Kampen: Kok.

Van Niftrik, G C 1944. Kleine Dogmatiek. Callenbach: Nijkerk.

Van Selms, A 1952. Lig uit lig: Die Christelijke geloof volgens die belydenis van Nicea. Kaapstad: HAUM.

Van Staden, P 1994a. Mag "slegs blankes" hier aanbid? HTS 50, 713-729.

- 1994b. Woordverkondiging: 'n Universeelgerigte aksie. HTS 50, 1041-1069.

Van Wyk, I W C 1994. Nog geslote eredienste?, Deel 1 en Deel 2. HTS 50, 755-779; 1070-1093.

- 1995. Die gemeenskap van die heiliges. HTS 51, 732-752.

- 1996a. Etiek in die nuwe Suid-Afrika. HTS 52, 165-178.

- 1996b. Het die kerk 'n politieke verantwoordelikheid? Oor die noodwendigheid en grense van die twee-ryke-leer. HTS 52, 765-799.

Van Wyk, J H 1996. Gedagtes oor eenheid en verskeidenheid in die kerk. Die Kerkblad 14 Augustus 1996, bl 28-30. 
Vischer, L 1965. Die Einheit der Kirche: Material der ökumenischen Bewegung. München: Kaiser. (ThB 30.)

Weber, O [1962] 1972. Grundlagen der Dogmatik. Band 2.2.Aufl. Neukirchen: Neukirchener Verlag. 